\title{
Place-Based Philosophical Activism on the US-Mexico Border
}

\author{
Mariana Alessandri \\ Department of Philosophy, University of Texas Rio Grande Valley, ELABS 342, 1201 University Drive \\ Edinburg, TX 78539, USA. \\ Corresponding author. Email. mariana.alessandri@utrgv.edu
}

(Received 27 September 2019; revised 29 December 2020; accepted 3 January 2021)

\begin{abstract}
Before the Department of Homeland Security instituted the Migrant Protection Protocols in January 2019, as many as 1,000 Central American refugees passed each day through Catholic Charities' Humanitarian Respite Center, where they received food, clothing, a shower, toiletries, and sandwiches for the road. Sister Norma Pimentel founded the Humanitarian Respite Center in 2014 to "restore human dignity" to refugees who had been degraded and vilified during their dangerous journeys north, not least by way of their processing by the US government. Sister Norma has inspired countless people, including me, to engage with the community as a form of place-based philosophical activism, that is, of situated and engaged teaching, scholarship, and service. In this essay I read Sister Norma as a feminist pragmatist in the historical and philosophical lineage of Jane Addams, and I aim to provide an example of how a feminist-pragmatist approach can support and encourage philosophical activism in our communities. Feminist scholars can learn from feminist pragmatism the importance of "being-with," "sympathetic understanding," and "a larger social impulse." Feminist pragmatism encourages academics to become place-based philosophical activists who use their teaching, research, and service in order to press for social justice.
\end{abstract}

In September 2017, Pope Francis urged his followers to welcome migrants and refugees "con brazos abiertos" (with open arms). By then, South Texas's Rio Grande Valley (RGV) had already become a major crossing point for Central American immigrants from the Northern Triangle: Honduras, El Salvador, and Guatemala. Between 2014 and 2019, more than 100,000 immigrant families surrendered their bodies to Border Patrol officers, who processed and released them to the bus station in McAllen (Catholic Charities n.d.). Before the Department of Homeland Security instituted the Migrant Protection Protocols (known commonly as the Remain in Mexico Policy) in January 2019, as many as 1,000 individuals passed each day through Catholic Charities' Humanitarian Respite Center (HRC), a shelter in which they received food, clothing, a shower, toiletries, and sandwiches for the road (Hernandez 2019). Norma Pimentel, a sister of the Missionaries of Jesus, founded the HRC in 2014 to

(c) The Author(s) 2021. Published by Cambridge University Press on behalf of Hypatia, a Nonprofit Corporation. This is an Open Access article, distributed under the terms of the Creative Commons Attribution licence (http://creative commons.org/licenses/by/4.0/), which permits unrestricted re-use, distribution, and reproduction in any medium, provided the original work is properly cited. 
"restore human dignity" to the people who had been simultaneously victimized and vilified during their dangerous journeys north. ${ }^{1}$

Sister Norma has inspired countless individuals, including me, to engage with the community as a form of "place-based philosophical activism," that is, of situated and engaged teaching, scholarship, and service. Inside the discipline of philosophy, through figures like Jane Addams, feminist pragmatism has long nudged scholars to explicitly situate what they do in the classroom into their larger political and social context. Now the nudge comes not from a trained philosopher but from Sister Norma, whom I read as a contemporary model of feminist pragmatism in the historical and philosophical lineage of Jane Addams. Like Addams and other feminist pragmatists, Sister Norma weaves her ethical commitments into her community action, and her embodied philosophy sounds the notes of Addams's concepts of "being with" (or coming alongside others), "sympathetic understanding," and a "larger social impulse." My analysis shows that feminist pragmatism offers concrete strategies for feminist scholars today; we can learn from Addams and Sister Norma how to practice placed-based philosophical activism. Philosophical activism refers to the critical, reflective practice of situating issues in a particular place and time, and then using the tools we have to get involved in these issues from our roles as organic intellectuals, philosophy professors, or ordained nuns. I offer this essay as testimony to the idea that a philosopher inspired by feminist pragmatism can practice place-based philosophical activism in fulfillment of their obligations to teaching, research, and service.

My first section introduces Jane Addams's feminist pragmatist work with immigrants in Chicago as a model of place-based philosophical activism. I show how three Addams-inspired concepts - "being-with," "sympathetic understanding," and "a larger social impulse"-can orient us toward contemporary issues in our own communities. On the South Texas border, one live issue is Central American immigration, which Sister Norma has been attending to since 2014. I read Sister Norma's activism through the lens of Addams's feminist pragmatism and show how she practices three of Addams's main tenets. Although Sister Norma is not as explicitly philosophical as Addams, it would be an injustice to reduce her to a "do-gooder" or "saint." When such labels are pasted onto social-justice-oriented Catholic nuns and laywomen like Addams - and they often do-it not only minimizes their contribution but neutralizes their radical stance and renders them toothless. To regard Sister Norma as a mere "do-gooder" is to refuse to cast her as a gritty and robust activist whose work organically lives by three central tenets of feminist-pragmatist philosophy. In the final section of the essay, I offer my own place-based philosophical activism as an example of contemporary feminist pragmatism at work. Because pragmatists value teaching so highly, throughout the essay I refer to my work with students in our communities. These examples offer the added benefit of showing how place-based philosophical activism affects students' lives.

It is a good time for feminist pragmatism to gain momentum within the discipline of philosophy. As an embodied, relational, activist-oriented, and pragmatically grounded philosophy, it is powerful enough to steer feminists interested in (but perhaps intimidated by) place-based philosophical activism through two mazes: 1) the complex and often bewildering ills in our society, and 2) the seemingly endless demands on our time. I hope this essay will tempt scholars to adopt a feministpragmatist approach and respond to its call to practice place-based philosophical activism. 


\section{Feminist Pragmatism and Jane Addams}

Feminist pragmatism borrows from classical American pragmatism a privileging of lived experience over theory, and from feminism a commitment to social justice (Whipps and Lake 2020, 1, 12). Contemporary feminist pragmatists Marilyn Fischer, Maurice Hamington, Danielle Lake, Charlene Haddock Seigfried, and Judy Whipps take inspiration from women-some academics, not all-in history who argued in word and deed for the rights of vulnerable populations (Seigfried 1996; 1998; 1999; Fischer 2004; Whipps 2004; Hamington 2010; Fischer 2011; 2014; Lake 2014; 2015; Fischer 2019; Whipps 2019; Whipps and Lake 2020). Some of the values that feminist pragmatists are committed to include: a) reflecting on concrete experience, b) epistemologies "based in experience and relationality," c) public engagement in the form of "place-based local activism," d) education, e) social action, f) participatory democracy, and f) pluralism (Fischer 2010, 94-95; Whipps and Lake 2020, 12-26). Jane Addams has long been recognized as a feminist pragmatist whose philosophical activism inspired others, most notably John Dewey (Seigfried 1999).

I read Addams as the first feminist pragmatist who welcomed immigrants con brazos abiertos. A hundred years before Sister Norma and 1,400 miles north of the Rio Grande Valley, Addams began to "restore human dignity" to immigrants through philosophical activism. With Ellen Gates Starr, Addams founded Hull House in 1889, calling it an "experimental effort to aid in the solution of the social and industrial problem," which affected the lives of recent and established eastern European immigrants on the near west side of Chicago (Addams 1910/1981; 98; Whipps 2019, 318). The predominantly female residents who lived at Hull House offered the community free concerts, lectures, and classes, in addition to food, health care, and child care (Burnier 2019, 2; see also Jane Addams n.d.). Addams described her work at Hull House as a "response to the needs of all the people" (Addams 1907/2003, 92; Whipps 2019, 318). The philosophy behind Hull House's response to the needs of the people can be theorized by using three concepts: being-with, sympathetic understanding, and a "larger, more general social impulse" (Addams 1905, 16; 1912, 11).

Not satisfied with the talking-about that often takes place in the ivory tower and political arena, Addams practiced being-with working-class immigrants in Chicago. Like all pragmatists, including John Dewey, William James, and Charles Sanders Peirce, Addams insisted that experience ground theory (Whipps and Lake 2020). Being-with is valuable to feminist pragmatism, in part because it gives rise to what Addams called "sympathetic understanding," which describes less an attitude than a commitment to thinking differently. Sympathetic understanding involves more than processing information we already have; it means opening our minds wide enough to consider certain kinds of (perhaps previously disregarded) information as knowledge. Finally, the third philosophical concept that we see play out in Hull House is Addams's idea that charity, as it was commonly understood and practiced then, was not the path to philosophical activism. In 1905 Addams called instead for a "larger, more general social impulse" (Addams 1905, 16). In the remainder of this section I expand on these three concepts central to Addams's philosophical activism.

Addams blamed the injustices in her society on a "lack of imagination," which, she lamented, "prevents a realization of the experiences of other people" (Addams 1902/ 1920, 9-10; Seigfried 1999, 209). A lack of imagination can lead us to limit our interaction with people who are not like us, which, Addams believed, has the detrimental effect of "not only circumscrib[ing] our range of life, but limit[ing] the scope of our 
ethics" (Addams 1902/1920, 10). Addams intentionally built connections with a variety of diverse peoples, and as Addams scholar Danielle Lake points out, "Addams's lifelong work can be seen as an effort to build and foster 'joint associations' where co-action is more likely to work effectively" (Lake 2014, 82; see also Whipps 2004, 122). Opening our minds is not always a matter of the will; it often takes putting ourselves in new or uncomfortable situations to begin to think differently. Addams knew that imagination alone is often insufficient to open the mind, so she called people to come and work alongside her. A commitment to being-with the community afforded Addams and the other Hull House residents a chance to foster sympathetic understanding.

Addams used the term sympathetic understanding sparingly, but scholar Charlene Haddock Seigfried and others have recovered and developed it as a fundamental part of Addams's philosophy. As Seigfried explains, "for pragmatists, scientific understanding is engaged, not distanced, and sympathetic understanding is a valuable aspect of experimental inquiry" (Seigfried 1999, 217). Addams first used the term in 1912 in A New Conscience and an Ancient Evil, where she explained:

Sympathetic knowledge is the only way of approach to any human problem, and the line of least resistance into the jungle of human wretchedness must always be through that region which is most thoroughly explored, not only by the information of the statistician, but by sympathetic understanding. (Addams 1912, 11)

Even if someone had researched a given societal ill to the point where they could recite statistics from memory, Addams believed that absent sympathetic understanding, they would fail to administer good solutions. Addams complained that "there are many people in every community who have not felt the 'social compunction,' who do not share the effort toward a higher social morality, who are even unable to sympathetically interpret it" (Addams 1902/1920, 71). Approaching a problem with sympathetic understanding involves looking at it from multiple angles and experientially growing the imagination to represent various viewpoints (albeit always imperfectly).

Sympathetic understanding is an easy concept to misunderstand because the term sympathy often connotes top-down feelings of pity or paternalism. On the surface, it also sounds like empathy, which Addams scholar Judy Whipps describes as "coming alongside others and working to understand their lived experience as a basis of democratic change" (Whipps 2019, 319). In her reply to Lorraine Code, Seigfried implies that sympathetic understanding could be a response to Gayatri Spivak (Spivak 1988):

The pragmatist theme of the pluralism of perspectives and their concern to recognize and acknowledge the values and realities of others differently situated by gender, ethnicity, class, and so on, from oneself, leads them to emphasize sympathetic understanding as a precondition for acquiring knowledge. Without such a predisposition sympathetically or empathetically to enter into the world-views of others, genuine reciprocal dialogue cannot take place. This is not empathy understood as already knowing how others feel, but a realization that I am unlikely to intuit how others not in my situation feel and therefore need to let them reveal themselves and their world. Addams is particularly astute in exposing her own elitist presuppositions and in devising ways not only to "let the subaltern speak," but to work together in ways that are empowering rather than demeaning (Seigfried 1998, 26). 
Sympathetic understanding is neither sympathy nor empathy; it is a commitment to hear and think better, and it flourishes when I commit to being-with people whose experiential background differs greatly from mine. As Lake points out, sympathetic understanding "requires more than the tolerating of difference. It calls on us to actively seek out the perspective of others" (Lake 2014, 84). In practicing sympathetic understanding, Addams believed we can "gain insight into the individuated worlds of experience of others and the values they hold that make these worlds cohere" (Seigfried 1996, 222).

An example of sympathetic understanding can be found in Hull House's Labor Museum, which displayed traditional spinning wheels for older women to display their talents. In Twenty Years at Hull House, Addams recounted how Italian, Russian, Polish, Syrian, Greek, and Irish mothers would light up in this space, their fingers reminding them of their expertise (Addams 1910/1981, 173-75). ${ }^{2}$ Marilyn Fischer points out that in this practice, "Addams advocates replacing hierarchy with democracy, defined as a way of associating with others through concrete experience and sympathetic understanding" (Fischer 2004, 86). Fischer adds:

In Democracy and Social Ethics, written for members of privileged classes, Addams argues that sympathetic understanding and reciprocity are essential practices for enacting social democracy. The knowledge required to heal fractured relationships and bring needed industrial and social reform could only be obtained through sympathy and shared, concrete experience. Addams understands democratic equality in terms of reciprocity, that is, that all people can simultaneously learn from and teach one another. As sympathetic understanding and reciprocity are internalized in attitude and expressed in action, the attitudes and beliefs that maintain power structures of privilege will be undermined. (Fischer 2010, 93-94)

Since democracy and pluralism are so important to feminist pragmatists, it is crucial that we find ways to learn about the situations of others, even people we disagree with. Sympathetic understanding is a powerful-but easily misunderstood-concept for feminist pragmatism, and for Sister Norma, as we'll see in the next section.

In "The Immigrants and American Charities" from 1905, Addams applauds her listeners at the Illinois Conference of Charities but also condemns the "old" idea of charity, saying that "one should like to make a plea that we take some pains to know immigrants as they are, in their ordinary occupations, to cultivate kind relations with them and not to turn them over so completely to charity" (Addams 1905, 15). At the time, Addams lamented:

We do not, for the most part, know them socially. We do not, for the most part, care to know the various languages they speak, or even the one language which our nearest neighbors may speak. We do not take very much pains with the history they represent, or the traditions they bring here, and it is only when we are forced into contact through our sympathies, upon the humanitarian side, that any real intercourse is established. (13)

Finally, Addams suggested that her listeners "supplement [their] charitable impulse with the larger, more general social impulse" (16).

As we know, charitable work does not automatically foster sympathetic understanding, but as Lake shows, sympathetic understanding can help people shed their simplistic 
notions of charity: "sympathetic understanding is a keystone toward effective collaboration; as Addams's careful articulation of sympathetic understanding separates it from a more common and simplistic understanding of charity" (Lake 2014, 84). For Addams, "real intercourse" with the community can inspire this "larger, more general social impulse" (Addams 1905, 16). Sister Norma embodies and encourages this social impulse even though she runs what is labeled a "charity." I now turn to Sister Norma's organic feminist pragmatism to show how she practices "sympathetic understanding," "being with," and a "larger, more general social impulse" and in so doing, calls members of her community to practice place-based philosophical activism alongside her.

\section{Sister Norma's Feminist Pragmatism}

In 2017, Sister Norma published a short essay titled "Immigrant" for The Pope Francis Lexicon. Here we get a snippet of Sister Norma's background, much like the first few chapters of Addams's Twenty Years at Hull House.

Sister Norma describes her upbringing as entre mundos (between worlds). Born in South Texas in 1953 to Mexican parents, Sister Norma grew up on both sides of the then wall-less border. Her bilingual and bicultural childhood meant spending time with immigrants and nonimmigrants alike; there was no pressure to distinguish between them. Recalling the Pope's command "to respond in a way which is always humane, just, and fraternal," Sister Norma remembers growing up in a United States that she called kind (Pimentel 2018, 93). As a young nun, Sister Norma lived in a convent with her (now-deceased) mentor Sister Juliana Garcia, and she recalls how Border Patrol would call Sister Juliana in the middle of the night asking her to house a Central American family for a few days. In 2014, instead of the Border Patrol calling Sister Juliana, it was McAllen's mayor, Jim Darling, calling Sister Norma Pimentel, Executive Director of Catholic Charities for the diocese of Brownsville. And instead of housing one family in her convent, Sister Norma founded the Humanitarian Respite Center to house hundreds of families. The volunteer-run shelter was Sister Norma's response to the mayor's call. ${ }^{3}$

Sister Norma was asked to aid the hundreds of immigrants who were being "caught" and "released" daily by Immigration and Customs Engagement (ICE). Immigrants who were deemed safe enough to be released obtained bus tickets to reunite with family members in other parts of the United States where they would await their court dates. Quickly, the McAllen bus station became overwhelmed with the extra demand. Sister Norma asked Sacred Heart Catholic Church in downtown McAllen near the bus station if she could borrow the parish hall to take care of people "for a few days" until the bus station could figure out how to meet the additional needs. Fr. Thomas Luczak agreed, and with help from the community, Sister Norma opened the HRC. Volunteers from all over the country-religious and nonreligious-began to gather in McAllen to help. Five years and four locations later, the process remained the same: seven days a week, usually more than twice a day, a volunteer would wait at the bus stop to offer hundreds of immigrants a chance to eat, shower, rest, and make a phone call. As late as December 2018, if the asylum-seekers were lucky enough to be released, the immigrant's first gift from the US was an ankle monitor. This kept them out of detention, but it was morally fetid, as it criminalized and stigmatized them I witnessed their second gift on many occasions from 2014-2019: a standing ovation when they walked through the Humanitarian Respite Center doors, welcoming 
them to the US and acknowledging their bravery. They received clothes and shoes (when there were enough), medical attention, hot soup, hygiene products, and to-go bags with food for what they prayed would be the last leg of their journey (Catholic Charities n.d.). Parents of babies also received disposable diapers and formula. When McAllen and the HRC would appear in the national news, donations would spike high enough to buy the children a toy for the road. Sister Norma credited the HRC's success to the generosity of the Rio Grande Valley community. In addition to donating goods, she says they also "gave lovingly of their time" (Pimentel 2018, 92). ${ }^{4}$

Unlike Addams, Sister Norma is neither a writer nor a philosophically trained intellectual. In my experience, her political, social, and theological positions have to be wrangled out of her in the form of speeches and interviews she is asked to give all over the country. But as feminist pragmatists Lake and Whipps have said about the process of recovering early feminist pragmatists, "we often have to look beyond academic philosophy to find the women who were influential social philosophers" (Whipps and Lake 2020, 2). Some of these early women were, like Sister Norma, organic intellectuals, "college educated activists rather than professional academic philosophers" (4). Feminist pragmatists take seriously as intellectuals women who were not trained as philosophers but who "were continuously involved in fighting oppression, especially of women, children, and minorities" (13). We don't need to call Sister Norma a philosopher to read her actions in conversation with feminist pragmatism. But it's critical that we read her as a feminist activist: feminist, insofar as she has worked longest with vulnerable women and children, and activist, insofar as she uses her power and role to sway others to join her work. Sister Norma is not Jane Addams, but she is a feminist pragmatist; the Humanitarian Respite Center is not Hull House, but it is a site where "being-with," "sympathetic understanding," and a "larger, more general social impulse," are fostered (Addams 1905, 16). Like Addams, Sister Norma advocates for the humane treatment of immigrants to the US, and her acts have sparked hundreds, if not thousands, of religious and lay people to join in her mission to "restore human dignity" to the men, women, and children who passed through the HRC every day for five years. Both Addams and Sister Norma embody a "come-and-see" attitude, believing that if you spend time with immigrants, change will take place on the inside and the outside. Like Addams did in the first decades of the twentieth century, a hundred years later Sister Norma practices "being-with," "sympathetic understanding," and a "larger, more general social impulse."

\section{Being-With}

Sister Norma points out that we have a lot to learn from the immigrants at the Humanitarian Respite Center even if we do not spend a lot of time with them. The important thing is to be with them and not just talk about them. Sister Norma has convinced me that one ought to resist talking about the immigration crisis on the USMexico border if one has not been-with the immigrant population on the border. When President Trump traveled to McAllen, Texas, in the summer of 2019 to investigate the border crisis, he refused to visit the HRC even after having been personally and publicly invited by Sister Norma in the Washington Post (Pimentel 2019). Had Trump visited the HRC, he would not have found "rapists" and "murderers," but frightened families fleeing the violence overwhelming their home countries. Pragmatists value experience, and the HRC provides people with experience in the form of being-with.

Can-stacking is a good example. At the HRC, immigrants were sometimes asked to help unload and organize donated goods. As I broke down cardboard boxes behind the 
HRC one day in 2018, I watched two men, no doubt tired from their crossings, carefully fill a storage unit with tin cans. Admittedly, these Central American men were far from displaying expertise like the eastern European women that Addams wrote about, but their bodies communicated a work ethic that is perpetually denied by anti-immigrant rhetoric. Their eagerness to stack cans may have been motivated by gratitude, a desire to help, or even boredom, but each can they stacked returned to them some of that dignity that had been stolen from them on their journeys north, including by Border Patrol. One man's son was playing in the dirt close by (no doubt instructed to stay close for fear of separation), and this child had the opportunity to watch his father, in Sister Norma's words, regain his dignity. This activity on this particular day may have been temporary and spontaneous, but it was co-creation, akin to Addams's beingwith. The result of such a scene is not pity but respect, what Addams called "kindly fellowship, and a real understanding" (Addams 1905, 12).

\section{Sympathetic Understanding}

Marilyn Fischer warns us of the potential pitfalls of promoting a concept like sympathetic understanding, which attempts to bridge the gap between the socioeconomic haves and have-nots. She writes:

A worry for feminists is that when members of a dominant group seek connections with groups of lesser power and social standing, their efforts may be paternalistic or smothering. Even with good intentions, members of the dominant group may not recognize or adequately respect the perspectives of the other. The task is to seek connection while respecting pluralism. This is not easy to do. There is no neutral stance; invariably, one cannot "understand" another's perspective, without using constructs and terms that make sense within one's own perspective. (Fischer 2010, 94)

Sympathetic understanding-the ability to read a social issue from multiple angles because one has grown one's imagination through meaningful interaction with others; actively seeking out the perspective of others on the assumption that their ideas are coherent; gaining insight into the values and experiences of others that lead to their choices-is made possible by being-with others. Still, it is not easy to get right; sympathetic understanding falls victim to false starts, mistakes, and the need for redos. The good news is that pragmatism values an experimental approach to social problems (Whipps 2019). There is, for pragmatists, no other way to begin. In becoming philosophical activists, we will necessarily make mistakes (perhaps even of this paternalistic variety), but not becoming philosophical activists for fear of making mistakes is no solution. ${ }^{6}$ It is awkward to put oneself in unfamiliar circumstances and risk the kinds of criticism that Fischer points to above. It is safer to stay at home than to try to foster sympathetic understanding by working alongside people condemned to the periphery - the geographical periphery of the US-Mexico border in addition to the socioeconomic, linguistic, cultural, and religious peripheries. If we stay home, no one can charge us with paternalism. Yet feminist pragmatists like Jane Addams and Sister Norma invite us to take the risk. Risk we do, and so do our students.

It is not easy to visit the HRC for the first time, and my students tend to get intimidated before they go. They do not know what to expect, and they worry that they are inadequate to the task. One of the courses in which I assign hours at the HRC is 
designed with sympathetic understanding in mind. Foregrounded in this course are the themes included in the course's title, "Ethics, Happiness, and the Good Life," but as we live on the US-Mexico border, the background of the course is the ethics of immigration.

All students in this course are required to spend fifteen hours at the HRC throughout the semester, but before beginning their hours they answer the question: "What is my responsibility toward the immigrant?" At the end of the course, after working alongside refugees and studying 1) Kant's Categorical Imperative, 2) Mill's Utilitarian framework, 3) Kierkegaard's interpretation of the biblical injunction to "love thy neighbor," and 4) Levinas's concept of "the face," students write a final essay answering the same question about their responsibility toward the immigrant.

Before their first day at the HRC, I ask the students not to probe into the personal life of anyone they meet there. Aside from that, I tell the students just to show up, to put themselves in an uncomfortable position in order to spend time with people whose life circumstances do not match theirs. (In the case of some students on the South Texas border, their life circumstances actually do match those of the immigrants: I have had students report that their experience inspired a conversation with parents who crossed over years ago.) And just as Addams noticed, when people show up, something important happens.

After their experience at the HRC, the students do not report gaining a newfound sense of sympathy. They've gained knowledge. Addams was right that undergoing this human experience would give them the kind of knowledge she called sympathetic understanding (Addams 1912,11). The students learned by occupying the same space as other people, by being-with immigrants and fellow volunteers. Afterwards, and as a consequence of ceasing to approach immigration as mere "statisticians" (as they had done when their primary source of knowledge was the nightly news), the students gain a fuller sense of why immigrants would trade their home country for the perils of a trip north to an uncertain future.

\section{A Larger Social Impulse}

Addams wanted her contemporaries to adopt a "newer" attitude toward immigrants, one that would extend beyond "charity" into a "larger, more general, social impulse" (Addams 1912, 11). From the outside it really looks like Sister Norma has set up a typical "charity" (it is, after all, funded in part by Catholic Charities). Still, I believe that the HRC cultivates in its volunteers, and perhaps in the immigrants themselves, Addams's "larger, more general, social impulse."

In the first place, the HRC is not explicitly religious. The only physical references to Catholicism are found in a couple of paintings and statues hanging in the HRC, along with the Missionaries of Jesus habit that Sister Norma wears daily (which looks more like a suit than a traditional habit). No volunteer or immigrant was to be asked what religion, if any, they practiced, and they were explicitly told not to proselytize or try to convert the immigrants. The current location of the HRC is still open but is mostly vacant due to the Remain in Mexico policy, and it is supported and run by the community, religious and nonreligious alike (Pimentel 2018, 92).

Addams claimed that the "newer attitude" she was looking for from her society would come from spending time with immigrants (Addams 1905, 15). I took my kids to the HRC to play with the children there, in part on the understanding that kids do not care about immigration status. It may be tempting-and it may even be 
justified-to criticize their play as an act of "charity." But if it is charity, it is also more than that. Although the standard power differentials do not cease to exist in the space of play, between citizen and noncitizen, between differing levels of formal education, between those who can go home and those who don't know where home is, I didn't feel like a university professor "slumming it" with her children. If I had I may not have gone, and I am not convinced that staying away on principle is a better answer. Neither Jane Addams nor Sister Norma would advise us to stay home for fear of troublesome power dynamics. I saw the visit as something of a break from child care, and my children saw a roomful of children to play with. Despite the problems inherent in volunteerism, our visit gave both sets of children (and parents) a fundamental way to communicate; it built one small (and imperfect) bridge between similar creatures coming from dissimilar circumstances. As Seigfried reminds us, one of the pillars behind social democracy is that "the diversity of human experience should elicit sympathetic understanding" (Seigfried 1999, 223). Although I cannot erase the power differentials in the room, we will not reach sympathetic understanding by never stepping into the room at all.

Despite the fact that volunteers at the HRC work with recent arrivals who often leave within twenty-four hours, instead of with permanent residents with whom they could share their lives, it is enough time to cultivate Addams's "larger, more general social impulse" (Addams 1912, 11). It does not take long to see that refugees are not "rapists" and "criminals" (Trump 2015) but frightened mothers and fathers and children seeking protection and human opportunity. I am convinced that this is why Trump did not visit the HRC; it might have humanized the refugees to him, leaving him at risk of growing his social impulse. The short-term nature of the work can make the HRC look ineffective: it does not directly change policy regarding immigrants, and doubters might say that no lasting transformation can come from it. But this way of thinking dismisses the ways that being-with, sympathetic understanding, and cultivating a larger social impulse can make all the difference in the lives of volunteers and refugees.

In her own way, Sister Norma has built the HRC to enact Addams's "newer attitude" toward charity (Addams 1905, 15). Drawing on Pope Francis, she writes:

Pope Francis invites us to respond with mercy and love. We cannot remain indifferent to human suffering. We must come together with courage and determination to transform our world into a kinder and more merciful place through a "revolution of tenderness" as Pope Francis inspires us to do through his own personal witness of humility and tenderness in all that he does and says. (Pimentel 2018, 94)

Sister Norma is writing about communities, societies, and worlds. And although Addams did not use the term "revolution of tenderness" to describe what went on inside Hull House, it fits. And although "revolution of tenderness" sounds like an oxymoron-revolution is hard, tenderness soft-both the HRC and Hull House are powerful reminders of how humans qua tender beings can care for one another. Initiatives like the HRC help us cultivate the larger social impulse for which Addams advocated.

A teaching example on developing a larger social impulse: one student asked me to release her from the service requirement at the HRC. She had children and explained that she didn't have time to go. When I told her that I took my children with me to the HRC, and that they benefited from going, she seemed relieved. This student turned out to be one of those most moved by the experience. 
Figure 1. Untitled, by Bertha Cristal Reyna.

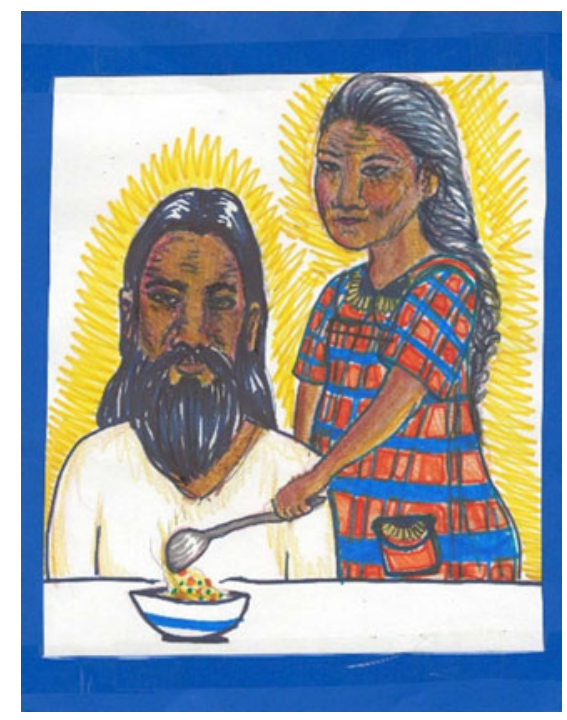

All of the students presented on their HRC experience during the last week of class, and they reported learning unforeseeable lessons. One student's written and oral presentation revolved around the theme of boredom; he concluded that the boring tasks that characterize care work may be the most important work a person can do. Other students reported an intention to keep volunteering. Most confessed that, prior to the readings and the HRC, they had no knowledge of immigration, even though droves of people were coming into the US, essentially into their backyard. One student artistically interpreted what goes on in the HRC (see Figure 1).

This student had interpreted the immigrant not as a rapist or a criminal, but as a dark-skinned Christ, being tended to by a dark-skinned woman in traditional dress, perhaps an immigrant herself, or perhaps Mary, his mother. They are both glowing. This drawing shows sympathetic understanding at work; after visiting the HRC, this student's perception of who is the caregiver and who is the receiver was reversed. The maligned immigrant is revealed to be God in disguise, and the dark-skinned female, normally thought to be the recipient of American charity, becomes the provider. Students and volunteers learn quickly that the old model of charity is not what goes on in the HRC. Being-with immigrants can help us cultivate a sympathetic understanding, which in turn will lead us to a larger social impulse.

\section{Feminist Pragmatism in Action}

In an article arguing that sympathetic understanding is necessary for good public administration, political scientist DeLysa Burnier reminds us that Addams was not always taken seriously as a "deep and complex thinker and activist committed to making all facets of American political, social, and economic life democratic, inclusive, and socially just" (Burnier 2019, 3). It wasn't until the 1990s that scholars across various disciplines began to describe her as more than a "saintly do-gooder," which is the way that people tend to speak about Sister Norma today. I do not want to wait ninety years to take Sister Norma seriously as a feminist pragmatist. 
Sister Norma Pimentel is not a contemporary Jane Addams, but her work represents feminist pragmatism in action. At the Humanitarian Respite Center, volunteers (who may themselves be immigrants) and immigrants (who often do volunteer work at the HRC) have a chance to be-with one another. This being alongside one another offers them an opportunity to foster sympathetic understanding, which in turn inspires in them the larger social impulse Addams was suggesting we adopt. I need only step into the world that Sister Norma has already created and invite my students to spend time with human beings whose humanity is jettisoned when they become the concept "immigrant." Jane Addams, Sister Norma, and other as-yet-undiscovered organic feminist pragmatists have forged the way for academics to practice place-based philosophical activism. We need not create these local community spaces; community activists do it already. But what a place-based philosophical activist should remember is not to look past our local communities toward some virtual horizon. Being-with, for Addams, meant being-with. It goes a long way to be in the physical presence of human beings who are read, instead, as headlines. Granted, modern technology extends the edges of our communities further than in Addams's day, but getting involved at the local level teaches students that their communities matter, not just their global community. One need not live in Chicago or the Rio Grande Valley to care about, be-with, learn from, imagine with, or act together with vulnerable populations, nor to grow one's sympathetic understanding and cultivate in oneself and one's students a larger social impulse. If we asked them how to respond to global concepts on the level of international humanitarian crises, Addams and Sister Norma would point us to our backyards. One need only look to one's town or city to see how activists are already responding to the societal ills of systemic racism, gender discrimination, environmental destruction, voter suppression, worker's rights, and so on. Especially in our internet age where the global feels local (and where we are tempted to forego the local for the global), turning students' philosophical gaze onto their own communities will help them value 1) their local communities and 2) their future communities. Place-based philosophical activism ensures that we don't live "out there" somewhere else, but here, now.

The legacy left by Addams and the one Sister Norma is creating are models for philosophical activism in our own communities. The central concerns of feminist pragmatism provide a good orientation for how to think about what kinds of projects would constitute meaningful place-based philosophical activism. Jane Addams and Sister Norma created for us 1) the conditions for being-with members of the community, 2) a chance to foster sympathetic understanding with them, and 3) the means for growing "a larger, more general social impulse" toward societal issues. As academics who are asked to teach, do research, and provide service to our institution and communities, we are in a good position to heed the call of feminist pragmatists like Jane Addams and Sister Norma to practice place-based philosophical activism. Thankfully, in most colleges and universities today, community engagement is looked on favorably, especially when students are involved.

\section{Notes}

1 In a personal conversation, Sister Norma told me that this phrase came to her spontaneously as a response to the mayor of McAllen asking: "What are you doing here, Sister?" "We are restoring human dignity," she replied.

2 Fischer elaborates on this point: "Maintaining respect was particularly difficult for immigrant parents of rapidly Americanizing children. Family cohesion was threatened as normal roles of authority were reversed. 
Children, as they learned English easily, became their parents' guides to American life and culture. In the process, the children lost respect for their parents, thinking they had little value in the American setting. Again, Old World cultural skills could serve to bridge these gaps. One of Addams's motivations for the Hull House Labor Museum was to give parents an opportunity to demonstrate their Old World craft skills at spinning, weaving, embroidery, metallurgy, and woodworking. By watching American museum visitors admire their parents' skills and the beautiful products they made, the children found new respect for their parents and accorded them dignity" (Fischer 2014, 42).

3 I have heard Sister Norma say this many times in many different contexts.

4 In the early years, Sister Norma bragged that the city of McAllen and the neighboring cities of the RGV support the HRC. In 2019, the HRC had to move locations in response to residents complaining about the immigrants, which was shocking for many in McAllen. See https://www.brownsvilleherald. com/news/local/mcallen-feeling-heat-after-forcing-respite-center-to-move/article_58d8d520-33b5-11e9885d-c3b914218468.html (accessed July 31, 2019).

5 Whipps and Lake add that the pragmatist feminists they are recovering "add dimensions to pragmatism; they remind us of the issues that were subsequently left behind as American philosophy became more exclusively technical and academic" (Whipps and Lake 2020,3)

6 Whipps points out the mistakes that Addams chronicled in Twenty Years as evidence of the experimental method. Likewise, the HRC is not without its missteps, which have to be corrected. In a personal conversation, Sister Norma recounted an episode in which a regular volunteer perpetually failed to respect the immigrants, bossing them around and treating them like children. After that Sister Norma posted signs at the HRC to remind volunteers that they are there to serve (Whipps 2019, 324; personal conversation).

\section{References}

Addams, Jane. 1902/1920. Democracy and social ethics. New York: MacMillan and Co.

Addams, Jane. 1905. The immigrants and American charities. Illinois Conference on Charities. Proceedings: $11-18$.

Addams, Jane. 1907/2003. Newer ideals of peace. In Jane Addams's writings on peace, vol. 1, ed. M. Fischer and J. Whipps. Bristol, UK: Thoemmes Press.

Addams, Jane. 1910/1981. Twenty years at Hull House. New York: Penguin Books.

Addams, Jane. 1912. A new conscience and an ancient evil. New York: The Macmillan Company. https:// hdl.handle.net/2027/hvd.32044038493441.

Burnier, DeLysa. 2019. Embracing others with "sympathetic understanding" and "affectionate interpretation:" Creating a relational care-centered public administration. Administrative Theory \& Praxis. $10.1080 / 10841806.2019 .1700460$.

Catholic Charities of the Rio Grande Valley. n.d. History of the Humanitarian Respite Center. https://www. catholiccharitiesrgv.org/respitecenter/History.aspx.

Fischer, Marilyn. 2004. Democracy and social ethics, and: The long road of woman's memory (review). Journal of Speculative Philosophy 18 (1): 85-88.

Fischer, Marilyn. 2010. Trojan women and devil baby tales: Jane Addams on domestic violence. In Feminist interpretations of Jane Addams, ed. Maurice Hamington. University Park: Pennsylvania State University Press.

Fischer, Marilyn. 2011. Interpretation's contrapuntal pathways: Addams and the Averbuch affair. Transactions of the Charles S. Peirce Society: A Quarterly Journal in American Philosophy 47 (4): 482-506.

Fischer, Marilyn. 2014. Addams on cultural pluralism, European immigrants, and African Americans. The Pluralist 9 (3): 38-58.

Fischer, Marilyn. 2019. Jane Addams's evolutionary theorizing: Constructing "Democracy and Social Ethics." Chicago: University of Chicago Press.

Hamington, Maurice, ed. 2010. Feminist interpretations of Jane Addams. University Park: Pennsylvania State University Press.

Hernandez, Sydney. 2019. Once holding 1,000 migrants, Respite Center sees dramatic drop, now helping homeless. Valleycentral.com, December 10. https://www.valleycentral.com/news/local-news/respite-center-sees-dramatic-drop-in-migrants-now-helping-homeless/.

Jane Addams Hull-House Museum. n.d. About Jane Addams. https://www.hullhousemuseum.org/aboutjane-addams. 
Lake, Danielle. 2014. Jane Addams and wicked problems: Putting the pragmatic method to use. The Pluralist 9 (3): 77-94.

Lake, Danielle. 2015. Dewey, Addams, and Beyond: A Context-Sensitive, Dialogue-Driven, Action-Based Pedagogy for Preparing Students to Confront Local Wicked Problems. Contemporary Pragmatism 12: 251-274

Pimentel, Norma Seni, MJ. 2018. Immigrant. In Pope Francis Lexicon, ed. Cindy Wooden and Joshua J. McElwee. Collegeville, Minn.: Liturgical Press.

Pimentel, Norma. 2019. Welcome to the border, Mr. President. The Washington Post. January 9.

Seigfried, Charlene Haddock. 1996. Pragmatism and feminism: Reweaving the social fabric. Chicago: University of Chicago Press.

Seigfried, Charlene Haddock. 1998. Perspectives on pragmatism: A reply to Lorraine Code. Radical Philosophy 92 (1): 25-27.

Seigfried, Charlene Haddock. 1999. Socializing democracy: Jane Addams and John Dewey. Philosophy of the Social Sciences 29 (2): 207-30.

Spivak, Gayatri. 1988. Can the subaltern speak? In Marxism and the interpretation of culture, ed. C. Nelson and L. Grossberg. Chicago: University of Illinois Press.

Trump, Donald. 2015 Presidential announcement speech. Time.com, June 16. https://time.com/3923128/ donald-trump-announcement-speech/.

Whipps, Judy. 2004. Jane Addams's social thought as a model for a pragmatist-feminist communitarianism. Hypatia 19 (2): 118-33.

Whipps, Judy. 2019. Dewey, Addams, and design thinking. In The Oxford handbook of Dewey, ed. Steven Fesmire. Oxford: University of Oxford Press.

Whipps, Judy and Danielle Lake. 2020. Pragmatist feminism. The Stanford Encyclopedia of Philosophy, ed. Edward N. Zalta. https://plato.stanford.edu/entries/femapproach-pragmatism/.

Mariana Alessandri is an Associate Professor of philosophy at the University of Texas Rio Grande Valley and is an affiliate faculty member in religious studies, Mexican-American studies, and gender and women's studies and is co-founder of PUEDE (Parents United for Excellent Dual Education), which advocates for and supports dual-language education in Rio Grande Valley public schools. She has published in The New York Times, New Philosopher, Womankind, Times Higher Education, and The Chronicle of Higher Education. She is the author of an upcoming book on seeing dignity in darker emotions.

Cite this article: Alessandri M (2021). Place-Based Philosophical Activism on the US-Mexico Border. Hypatia 36, 370-383. https://doi.org/10.1017/hyp.2021.17 